$\mathrm{P} 14$

Reconstruction of Late Jurassic Oolite Shoal Paleoenvironments in a Giant Gas Field, Onshore United Arab Emirates

D.A. Lawrence (Al Hosn Gas), F. Al Darmaki (Al Hosn Gas), D. Green (Badley Ashton \& Associates), Y. Bouzida (Baker Hughes) \& G. Popa (Al Hosn Gas) 


\title{
15115 Reconstruction of Late Jurassic oolite shoal paleoenvironments in a giant gas field, onshore United Arab Emirates
}

\author{
David A. Lawrence (Al Hosn Gas < david.lawrence@alhosngas.com>), Fatima Al Darmaki (Al Hosn Gas), \\ David Green (Badley Ashton \& Associates), Yasmina Bouzida (Baker Hughes) \\ and Georgeta Popa (Al Hosn Gas)
}

The Late Jurassic Arab Formation is being developed in a major gas accumulation located onshore in southern region of the United Arab Emirates (UAE). The reservoir intervals form a large-scale shallowing-upward cycle capped by the widespread Hith anhydrite topseal. The lower part of the Arab Formation consists of wackestones to mudstones of mid-ramp to basinal setting (Arab D Member) overlain by foreshoal and oolitic grainstone shoal deposit of the Arab C Member. The succeeding upper part of the Arab Formation (A and B members) comprises alternations of dolomitic limestone and anhydrite of restricted lagoon to backshoal and sabkha/salina origin.

The main Arab $\mathrm{C}$ interval comprises skeletal and ooid-rich wackestones and packstones grading upwards into oolitic grainstones (25-30 m thick package) interpreted as the progradation of foreshoal to ooid shoal environments. It has proven difficult to identify smaller-scale (amalgamated) cycles at the scale of individual shoal bodies. Conceptual facies models in such environments are qualitative and of little value in predicting reservoir heterogeneities. However, literature reviews, outcrop studies and analogues from producing fields demonstrate that reconstruction of oolite shoal sub-environments is fundamental to understanding initial depositional fabric, near-surface diagenesis and modification by later burial diagenesis.

This presentation examines the depositional architecture of oolite shoals at two different scales: (1) field-wide correlation of facies stacking patterns linked to seismic response over tens of kilometers (at the scale of 'mobile sand belts' in modern shelf-margin analogues); and (2) facies architecture in a $5 \mathrm{x}$ $5 \mathrm{~km}$ area of the field with multi-directional deviated and horizontal wells, enabling reconstruction of sub-environments at the scale of composite bar forms.

A key element to understanding reservoir architecture has been the integration of core descriptions with borehole image logs, permitting recognition and re-orientation of the main bounding surfaces, cross-bedding co-sets and individual sets. The following three sub-environments are recognized (from base to top): (1) a lower interval with isolated, mainly landward-directed (flood tidal?) planar cross-sets within burrowed packstones to grainstones. Tidal reversals become more frequent upwards. Deposition in offshore, linear mainly flood-oriented ooid sand ridges is interpreted. (2) A middle interval with amalgamated, multi-directional (mainly flood-oriented) cross-bedding interpreted as 3-D (parabolic?) ooid bars with flanking channels. (3) An upper interval dominated by low-angle stratified to massive/ burrowed grainstones, possibly indicating bar exposure or back-shoal settings.

Geometries, scales of cyclicity and facies distributions indicate analogs to modern tidally-influenced ooid tidal ridges and parabolic bars. Facies architecture and impact on reservoir quality will be examined through detailed cross-sections and horizontal well transects. 